\title{
Ewa Solarczyk-Ambrozik (red.), Doradztwo zawodowe w perspektywie całożyciowego uczenia się, Wydawnictwo Naukowe Uniwersytetu Adama Mickiewicza, Poznań 2016, ss. 304.
}

Globalizacja niesie za sobą wiele zmian, m.in. w gospodarce i na rynku pracy. W procesie zmian istotną rolę odgrywa doradztwo zawodowe, które pomaga odnaleźć się w świecie nowych technologii, zrozumieć zmiany, a także wydobyć i uszlachetnić indywidualne predyspozycje człowieka tak, aby były przydatne na rynku pracy.

Recenzowana publikacja złożona jest z wstępu, trzech części podzielonych na mniejsze podrozdziały, gdzie każdy z nich zakończony jest bibliografią. Część pierwsza książki zatytułowana została "Doradztwo zawodowe w perspektywie całożyciowego uczenia się - konteksty teoretyczne”. Ten fragment publikacji składa się z siedmiu podrozdziałów. Jerzy Bielecki w swoim artykule skupia się na kompetencjach, jakie powinien posiadać doradca zawodowy. Jego zdaniem fundamentem tego zawodu jest posiadanie wiedzy interdyscyplinarnej. Anna Kławsiuć-Zduńczyk z kolei zauważa, że doradca zawodowy to przede wszystkim osoba, która pokazuje możliwe kierunki, a nie dostarcza gotowych rozwiązań. Alicja Kargulowa podkreśla, że doradztwo stało się powszechne, że na rynku zaczęło pojawiać się wielu „prowizorycznych” radców. Przestrzega przed ich działami, apelując, że niejednokrotnie stwarzali oni zagrożenie dla osób korzystających z ich usług. Niezwykle istotny aspekt porusza Agnieszka Gromkowska-Melosik. Autorka zajęła się pojęciem doradztwa zawodowego $\mathrm{w}$ wymiarze wielokulturowym. Badaczka zaznacza jednak, że jest to zadanie niebywale trudne, gdyż kultura przyjęta przez doradcę bywa kontrastem kultury radzącego się. Kolejnym szeroko rozwiniętym pojęciem tegoż rozdziału jest pojęcie kariery. W artykule Ewy Solarczyk-Ambrozik czytelnik odnajdzie definicje kariery oraz kariery bez granic. Zadaniem tej drugiej jest zacieranie barier na ścieżce zawodowej i prywatnej. Odnosząc się do kariery, kolejna autorka - Agniesz- 
ka Cybal-Michalska - zauważa, że istotnym jej czynnikiem jest sukces. Dla jednych będzie to premia pieniężna, dla innych uznanie. Ostatni artykuł napisany przez Lucynę Myszkę dotyczy prorozwojowości.

Część druga książki nosi tytuł „Całożyciowe uczenie się i doradztwo zawodowe a rynek pracy - szanse i bariery”, składa się ona z siedmiu podrozdziałów. Bogusław Śliwerski zajął się analizą reform w systemie polskiej edukacji, jakie miały miejsce od roku 1989, i zauważył, iż kolejne zmiany w szkolnictwie doprowadzały do dezorganizacji szkół zawodowych oraz sprawiły, że uczniowie tego rodzaju szkół coraz częściej uważali się za mniej wartościowych ludzi i mało kompetentnych potencjalnych pracowników na rynku pracy. Badacz podkreśla, że do tej sytuacji przyczynili się nie tylko rządzący państwem polskim, ale także „czwarta władza, czyli media, których przedstawiciele albo opowiadali się za likwidacją szkolnictwa zawodowego, albo ośmieszali poziom takiego wykształcenia [...]” (Tamże, s. 116). W podrozdziale drugim tej części publikacji Ewa Skibińska wyjaśnia definicję i korzyści płynące z walidacji. Autorka twierdzi między innymi, że walidacja kompetencji przygotowuje człowieka do pracy i może stać się jego zabezpieczeniem na przyszłość. Akademickich biur karier dotyczy artykuł Daniela Kukli. Anna Wawrzonek zauważa, że środowisko pracy posiadające pracowników w różnym wieku narażone jest na wiele trudności. Przede wszystkim komplikacje można zauważyć w kodach komunikacyjnych. Apeluje jednak, że wykorzystywanie miękkich kompetencji, m.in. komunikatywności i elastyczności może ułatwić funkcjonowanie w międzypokoleniowym zespole. Uważa także, że pracodawcy nie powinni skupiać się na granicach i barierach, a właśnie na cechach wspólnych pokoleń. Monika Bartkowiak analizuje trend młodzieży w kierunku egzystencji konsumpcyjnej. Autorka uważa, że obecnie „żeby być, trzeba coś mieć”. Magdalena Barańska skupiała się na przedstawieniu wyników badań, których celem było „poznanie opinii studentów na temat sytuacji osób młodych na rynku pracy". Badania te dowodzą, że absolwenci uczelni wyższych nie mają poczucia bezpieczeństwa dotyczącego ich ścieżki zawodowej. Z raportu dowiedzieć się można także, iż obawy te spowodowane są faktem wymagania przez pracodawców doświadczenia, które w opinii studentów nie jest łatwe do zdobycia podczas studiowania. Ostatnia kwestia, poruszona przez Izabelę Cytlak, Joannę Jarmużek oraz Joannę Szafran, to utrudnienia pracowników związane z ich niepełnosprawnościami. Osoba niepełnosprawna poza przełamaniem swoich wewnętrznych hamulców musi także przebić się przez odgórne etykietowanie.

Trzecia - ostatnia - część książki pt. „Całożyciowe uczenie się w wybranych sytuacjach społecznych” składa się z pięciu podrozdziałów. Autorem 
artykułu na temat roli dyrektora szkolnego jest Małgorzata Rosalska. Autorka podkreśla, że zawód ten wymaga nie tylko wysokiego poziomu wiedzy naukowej, ale także wysokich kompetencji społecznych, organizacyjnych i przywódczych. Z przeprowadzonych badań wynika m.in. że dyrektorzy stawiają na stare, sprawdzone już metody pracy. Kolejny podrozdział skupia się na mentoringu. Autorka dostrzegła, że mentoring jest takiego rodzaju relacją, w której wiek nie ma znaczenia. Wręcz przeciwnie, podkreśla jak wiele korzyści płynie z intermentoringu. Joanna Szłapińska stara się uświadomić czytelnikowi, jak ważną rolę w życiu pełni praca, podejmując analizę tego zagadnienia w ujęciu diachronicznym, począwszy od XVI wieku aż po współczesność. Niezwykle interesującym - z punktu widzenia przyszłego pracobiorcy - może okazać się artykuł Elwiry Litaszewskiej dotyczący programów ambasadorskich. Programy te adresowane są do młodzieży akademickiej, która dzięki nim ma szanse zdobyć branżowe doświadczenie, certyfikaty, a także wiele innych materialnych i niematerialnych korzyści. Rolą ambasadora jest przede wszystkim stworzyć optymistyczny image pracodawcy. Ostatnia publikacja opisywanej części dotyczy networkingu i została napisana przez Różę Kowalską. Autorka pisze, że tak jak inne metody rozwoju zawodowego, tak i networking rządzi się pewnymi zasadami. Tworząc sieć kontaktów należy pamiętać o zachowywaniu etyki i lojalności.

Niniejsza publikacja jest ważną lekturą dla wielu kategorii osób. Zawiera wiele cennych informacji dla studentów, gdyż wskazuje istotne w ich procesie edukacji, a tak mało omawiane i nagłaśniane, Akademickie Biura Karier oraz programy ambasadorskie. Może okazać się pomocna dla samych doradców zawodowych, gdyż szczegółowo została opisana ta funkcja - od wyjaśnienia samej terminologii po rozszerzenie działań doradcy na płaszczyźnie wielokulturowej. Przede wszystkim jest to książka, której treści adresowane są do każdego człowieka, któremu nie jest obojętna jego przyszłość. Publikacja ukazuje skutki globalizacji i pozwala zrozumieć człowiekowi zastaną rzeczywistość. Czytelnik dzięki niej będzie w stanie zrozumieć, jak ważne jest to, aby edukować się przez całe swoje życie, gdyż tylko dzięki doskonaleniu swoich kompetencji będzie w stanie mieć wpływ na rozwój swojej ścieżki osobistej i zawodowej. 